\title{
SOWING AND PLANTING PERIOD ON YIELD AND EAR QUALITY OF SWEET CORN (Zea mays L. var. saccharata)
}

\author{
Épocas de semeadura e plantio sobre a produtividade e qualidade \\ de espiga do milho doce (Zea mays L. var. saccharata)
}

\author{
Atnan Ugur' ${ }^{1}$ Hande Ayhan Maden²
}

\begin{abstract}
Sweet corn (Zea mays L. var. saccharata) attracts people with its amazing flavour. Adverse environmental factors decrease plant's cob yield and quality. A more effective production can be made by using resistant varieties and adjusting the sowing and plating periods. In this study, the effect of direct seed sowing and cultivating with seedlings in three different times $(5,15$ and 25 May) on the sweet corn's cob yield and certain quality features have been investigated. In the research hybrid sweet corn varieties; 2201, Challenger, Merit, Sunshine and Yellow Baby were used. Ear weight, ear yield, ear length, ear diameter, sequence in ear, kernel numbers in the sequence, dry weight, TSS, chroma and hue values have been identified in the study. The values obtained from cultivation with seedling have been found higher in all of the parameters except for TSS. With the progress of cultivation period while TSS and hue values in kernels have increased (9.72 to 20.94) chroma values have decreased. Husked ear weight values have changed between 184.69 to $224.11 \mathrm{~g}$ in varieties. The highest ear yield $\left(3594.33 \mathrm{~kg} \mathrm{da}^{-1}\right)$ has been obtained from Merit by seedling planting cultivation on 15 May.
\end{abstract}

Index terms: Corncob, growing season, kernel, seedling.

\section{RESUMO}

$\mathrm{O}$ milho doce atrai as pessoas graças ao seu sabor surpreendente. Fatores ambientais adversos reduzem a produtividade e qualidade da espiga. Uma produção mais eficaz pode ser obtida usando variedades resistantes e ajustando épocas de semeadura e plantio. Neste estudo, os efeitos da semeadura direta e plantio sobre a produtividade em tres épocas diferentes $(5,15$ e 25 de Maio) e algumas características de qualidade foram investigadas no âmbito da produção de milho doce. As seguintes variedades híbridas de milho doce: Challanger, Merit, Sunshine e Yellow Baby foram usadas durante o estudo. Peso, produtividade, altura, diâmetro e número de linhas da espiga, número de grãos na linha, sólidos solúveis totais, valores de chroma e hue foram calculados. Durante esse estudo, foram observados valores maiores para todos os parâmetros exceto para sólidos solúveis totais. Com o passar da época de cultivo, os valores de sólidos solúveis totais $(9,72$ a 20,94) e os de hue aumentaram e os de chroma diminuiram. Valores de peso sem gluma variaram entre 184,69 a 224,11 g nas variedades do milho doce. A maior produtividade $\left(3594,33 \mathrm{Kg} \mathrm{da}^{-1}\right)$ foi obtida para a variedade Merit semeada em 15 de maio.

Termos para indexação: Espiga, época de cultivo, grão, muda.

\section{INTRODUCTION}

Fresh sweet corn (Zea mays L. var. saccharata) has been consumed widely by boiling or by grilling since past times. In Turkey, fresh corn is supplied from dent corn and flint corn mostly. Production and use of sweet corn has increased swiftly in recent years. Sweet corn is one of the most popular vegetables in the USA, Canada and Australia. It is becoming popular in India and other Asian countries. Sweet corn differs from other corns (field maize, popcorn and ornamental) because the kernels have high sugar content in the milk on early dough stage. It is consumed in the immature stage of the crop. The taste of sweet corn kernels is $25-30 \%$ sweeter than normal corn. At optimum market maturity, sweet corn will contain 5 to $6 \%$ sugar, 10 to $11 \%$ starch, $3 \%$ water-soluble polysaccharides, and $70 \%$ water. Sweet corn also contains moderate levels of protein, vitamin A (yellow varieties), and potassium (Najeeb et al., 2011; Walker, 2013). It can be consumed as fresh, frozen or conserved and also used particularly as garniture in the salads. In the last year's consumption of sweet corn as boiled ear increases in coastal regions rapidly.

Kernel colour, sugar rate and kernel yield are important characteristics for processing industry (Boyette; Wilson; Estes, 1990). Early and late out of season production in the sweet corn for fresh consumption is of great significance due to the high price of ears (Bozokalfa; Esiyok; Ugur, 2004). In sweetcorn produced for fresh

${ }^{1}$ Ordu Univ. Faculty of Agriculture - Departament of Horticulture 52200 - TURKEY - atnanugur@gmail.com

${ }^{2}$ Ordu Univ. Faculty of Agriculture - Departament of Horticulture 52200 - TURKEY

Received in july 17, 2014 and approved in september 15, 2014 
consumption, production in earliness and late season is highly important for providing the market with fresh crops. However, different seed sowing periods and seedling planting time are very important factors to extend growing season in different ecologies. Therefore, extended planting period makes crops get more exposed to stress caused by climate and environment. Sweet corn must be harvested during optimal maturity to obtain best eating quality, a finite capacity of vegetable processing facilities and steady demand for fresh produce necessitate all harvest period. Producers extend harvest by staggering planting dates and planting hybrids with different maturity dates (Williams, 2008). Likewise, some studies have been conducted in different ecologies regarding seed sowing periods and it has been identified that seed sowing times have an effect on ear yield and quality (Sari; Abak, 1997; Anil; Sezer, 2003; Bozokalfa; Esiyok; Ugur, 2004; Kwabiah, 2004; Lushsinger; Camilo, 2008; Williams, 2008). Generally while early seed sowing extends maturation process, late seed sowing shortens (Turgut, 2000; Idikut; Cesur; Tosun, 2005) Therefore the aim of this study is to investigate the effect of different sowing and planting periods on yield and quality in sweet corn in Black Sea Region, Turkey.

\section{MATERIAL AND METHODS}

Field experiments were conducted in 2009-2010 production seasons at the Ordu $\left(40^{\circ} 96^{\prime} \mathrm{N}, 37^{\circ} 96^{\prime} \mathrm{E}\right)$ ecological conditions, in Black Sea Region, Turkey. Temperature and humidity values recorded during research period were given in figure 1 .
The soil in the experimental area was clayey-loamy and contains low acid (pH 6.29) and has medium organic substance with $2.23 \%$. It was not possible to determine salt amount since it was very low. This soil also contained enough amount of nitrogen $(0.163 \%)$, low phosphorus (4.79 $\left.\mathrm{mg} \mathrm{kg}^{-1}\right)$, enough amount of potassium $\left(220 \mathrm{mg} \mathrm{kg}^{-1}\right)$, high amount of calcium (4985 mg kg-1), enough amount of magnesium (276 mg kg-1) (Kacar; Katkat, 1998). Trial area tillage deeply in autumn and according to soil analysis results 20-10-10 (N-P-K) $\mathrm{kg} \mathrm{da}^{-1}$ ground fertilizer was applied. In cultivation period fertilizer was given as 20 $\mathrm{kg} \mathrm{N}, 10 \mathrm{~kg} \mathrm{P}_{2} \mathrm{O}_{5}$ and $10 \mathrm{~kg} \mathrm{~K}_{2} \mathrm{O}$ as band.

2201, Challenger, Merit, Sunshine and Yellow Baby hybrid sweet corn varieties were sown and planted at three different dates $(5,15$ and 25 May). Seeds were sown 25 days before plating dates in plastic viols having turf:perlite (3:1) mixture and kept in unheated plastic tunnels till planting time.

The study was carried out as completely randomized experimental plan with three replications. Each plot was $5.0 \mathrm{~m}$ long x $1.2 \mathrm{~m}$ in wide. Sweet corn seeds were sown in double rows, $24 \mathrm{~cm}$ spaced with $60 \mathrm{~cm}$ row distance. Seedling, with 3-4 leaves, was planted into a $15 \times 15 \times 15$ $\mathrm{cm}$ hole filled with soil. Cultural applications such as irrigation, fertilization and weed control were realized completely and timely. When the ear silks turn brown was determined as harvest criteria. The first ear harvest was made on 15 July. The last harvest was made on 10 August. In the 10 plants from each parcel, ear weight, husked ear yield, TSS, chroma and hue ${ }^{\circ}$ colour values in

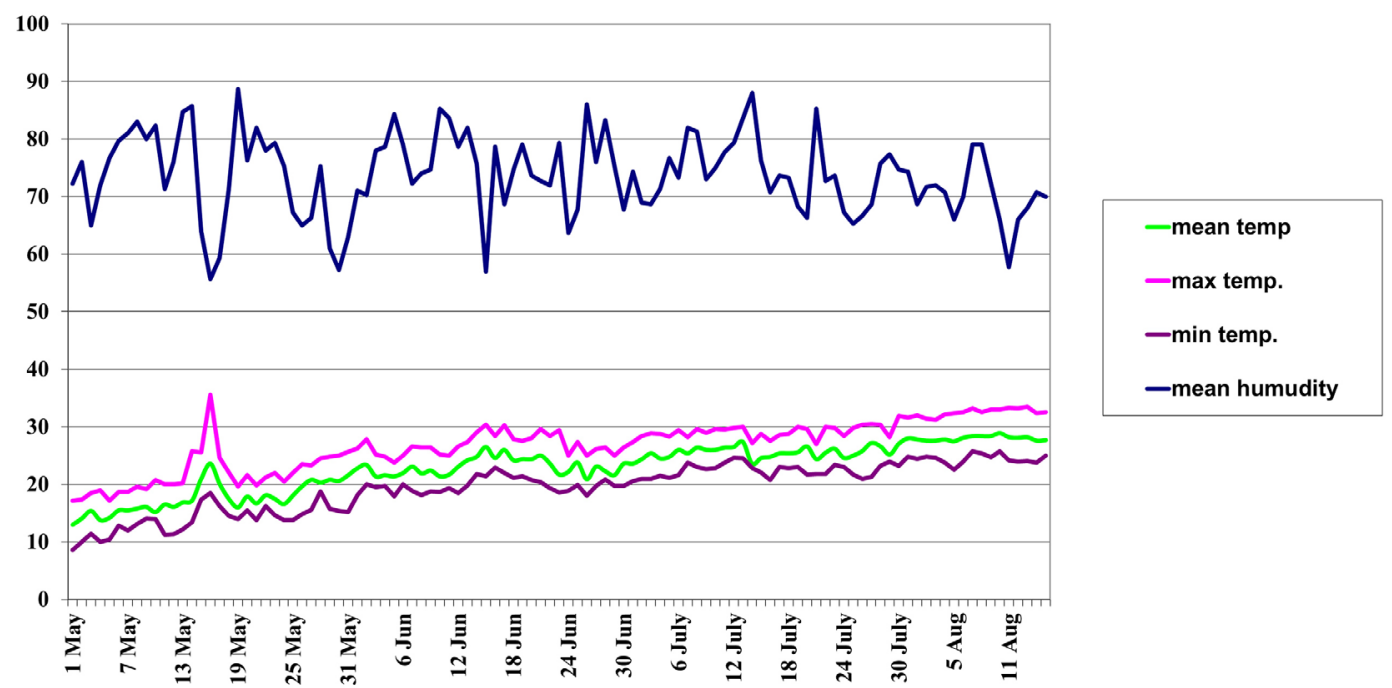

Figure 1 - Temperature and humidity values in experimental area, Ordu. 
10 ears were analyzed. Colour reading in kernel samples were determined in the manner that 10 readings in each cob as L, a, b with Konica Minolta CR-400 colorimeter. $\left(\right.$ Chroma $\left.=\sqrt{ } \mathrm{a} 2+\mathrm{b} 2, \mathrm{Hue}^{\mathrm{o}}=\tan -1(\mathrm{~b} / \mathrm{a})\right)$.

Statistical evaluation was made with the help of SPSS statistical package program. Mean separation of variety, cultivation types and dates effects in this study was accomplished using Fisher's protected least significant difference (LSD) test. Probability level lower than 0.05 were categorized as significant.

\section{RESULTS AND DISCUSSION}

\section{Plant height}

It has been observed that different seed sowing times and seedling cultivation are effective on the yield and some quality parameters of sweet corn. As to plant height values, cultivation with seedling has increased plant height (Table 1).

In sweet corn varieties, plant height changed 1.69-2.21. The plant height was higher in cultivation with seedling than in cultivation with direct sowing. Idikut, Cesur and Tosun (2005) and Williams (2008) reported that similar results. Generally, plant height values were decreased with a delaying sowing times. However, when the planting date was delayed an increase was observed in the height of plant. In terms of varieties, Merit had the highest plant height value $(2.20 \mathrm{~m})$ and the other varieties followed respectively by Sunshine, Yellow baby, 2201, Challenger. As the seed sowing dates are delayed the height of the plant has decreased. As the planting date delayed, seedling height increased. During vegetative progress of plants, a clear increase in the height has been observed in the last period of seedling cultivation due to humid air conditions. However, cultivation with direct seed sowing led to slow down in the development of the plant and plants ended up with lower heights since they entered generative period earlier as a result of the heat increase (Williams, 2008). According the previous studies (Turgut; Balci, 2002; Bozokalfa; Esiyok; Ugur, 2004; Idikut; Cesur; Tosun, 2005) plant height could be high in Ordu ecology as a result of the humid air conditions and the high number of cloudy days.

\section{Husked ear weight}

In sweet corn varieties, husked ear weight values have been found as $229.34 \mathrm{~g}$ in cultivation with seedling and $160.76 \mathrm{~g}$ in cultivation with seed (Table 2).

While husked weight values decreased in the late period in direct seed sowing cultivation, an increase observed in the late period in seedling cultivation. A statistically significant difference was found among varieties and Merit had the highest husked weight. Yellow baby, Sunshine, 2201 and Challenger varieties had constituted a statistically different group. Esiyok and Bozokalfa (2005) have stated that ear weight increased with seedling cultivation compared to seed sowing and delayed sowing and planting times result in the decreased ear weights in sweet corn. While the plants cultivated with direct seeding could not recover themselves due to environmental conditions, plants cultivated with seedling develop better both vegetatively and generatively.

\section{Ear yield}

When ear yield values in sweet corn variety were analyzed, it was found that planting type, variety and sowing and planting periods were statistically effective (Table 3).

Ear yield was higher in seedling cultivation $\left(2574.75 \mathrm{~kg} \mathrm{da}^{-1}\right)$ than in direct seeding cultivation (1159.85 $\left.\mathrm{kg} \mathrm{da}^{-1}\right)$ Delayed sowing and planting times led to decrease in ear yield. The highest ear yield was recorded as $3594.33 \mathrm{~kg} \mathrm{da}^{-1}$ in Merit by seedling cultivation on 15 May. It has been identified that the highest ear yield was observed in Merit (2349.00 $\left.\mathrm{kg} \mathrm{da}^{-1}\right)$ and Sunshine (2031.95 $\left.\mathrm{kg} \mathrm{da}^{-1}\right)$. It was stated by various researches that early and late sowing times adversely affect ear yield (Turgut; Balci, 2002; Oktem; Oktem; Coskun, 2004; Idikut; Cesur; Tosun, 2005; Williams, 2008).

\section{TSS}

While TSS values of kernel remained stable in sweet corn varieties according to cultivation types. As the cultivation period passed, an increase in TSS values has been observed (Table 4).

While the TSS values of the kernel in sweet corn varieties did not change according to seed sowing or seedling planting cultivation, there was an increase in the TSS values with delaying sowing and plating time. It is an expected consequence that the TSS values increase as a result of the decrease in the amount of water with maturation. It is desired that TSS value of sweet corn is high during fresh consumption. Varieties were divided into two groups statistically in terms of TSS values. It was observed that Yellow baby, Sunshine and Merit had higher TSS than 2201 and Challenger. TSS values have been consistent with previous studies (Esiyok; Bozokalfa, 2005; Esiyok; Bozokalfa; Ugur, 2004; Tuncay; Bozokalfa; Esiyok, 2005). 
Table 1 - Plant height values in sweet corn varieties (m).

\begin{tabular}{|c|c|c|c|c|}
\hline \multirow[b]{2}{*}{ Dates (A) } & \multicolumn{4}{|c|}{ Cultivation type } \\
\hline & Variety & Seed sowing & Seedling planting & Mean \\
\hline \multirow{6}{*}{5 May } & 2201 & 2.03 & 1.88 & 1.96 \\
\hline & Challenger & 2.03 & 1.73 & 1.88 \\
\hline & Merit & 2.36 & 2.07 & 2.22 \\
\hline & Sunshine & 2.19 & 1.94 & 2.07 \\
\hline & Yellow baby & 2.11 & 1.92 & 2.02 \\
\hline & Mean & 2.14 & 1.91 & 2.03 \\
\hline \multirow{6}{*}{15 May } & 2201 & 1.77 & 1.90 & 1.84 \\
\hline & Challenger & 1.58 & 1.53 & 1.56 \\
\hline & Merit & 2.09 & 2.32 & 2.21 \\
\hline & Sunshine & 1.93 & 1.88 & 1.91 \\
\hline & Yellow baby & 1.88 & 1.97 & 1.93 \\
\hline & Mean & 1.85 & 1.92 & 1.89 \\
\hline \multirow{6}{*}{25 May } & 2201 & 1.64 & 2.08 & 1.86 \\
\hline & Challenger & 1.48 & 1.80 & 1.64 \\
\hline & Merit & 1.94 & 2.44 & 2.19 \\
\hline & Sunshine & 1.73 & 2.06 & 1.90 \\
\hline & Yellow baby & 1.78 & 1.92 & 1.85 \\
\hline & Mean & 1.71 & 2.06 & 1.89 \\
\hline \multirow{5}{*}{ Variety (B) } & 2201 & 1.81 & 1.95 & 1.88 \\
\hline & Challenger & 1.70 & 1.69 & 1.69 \\
\hline & Merit & 2.13 & 2.28 & 2.20 \\
\hline & Sunshine & 1.95 & 1.96 & 1.96 \\
\hline & Yellow baby & 1.92 & 1.94 & 1.93 \\
\hline Cultivation type (C) & & 1.90 & 1.96 & \\
\hline
\end{tabular}

ns: no significant; $p<0.05 * ; p<0.01 * * ; p<0.001 * * *$.

\section{Kernel chroma values}

Cultivation period, varieties and cultivation type were statistically effect on kernel chroma values (Table 5).

Chroma values varied 64.37-74.71 in sweet corn varieties. Chroma value which displays the saturation of the colour was 71.67 in cultivation with seedling, 70.11 in cultivation with seed. As sowing and planting times passed, chroma values decreased. With the maturation in kernel colour, the saturation of the colour decreased. It can be stated that saturation of colour decreased, as kernel matured. The varieties divided into three statistical groups in terms of chroma values. Challenger had the highest chroma value of 72.70 by following, 2201, Yellow Baby, Merit and Sunshine, respectively.

\section{Kernel hue ${ }^{0}$ values}

Some differences was found between kernel hue values in sweet corn varieties (Table 6).

The hue value, indication of colour change between yellow and red increased with delayed sowing and planting time. The hue value was 179.59 in cultivation with seedling, 179.36 in cultivation with seed. Sunshine had the highest hue value with 179.80 and other varieties listed as Yellow baby, 2201, 
Challenger and Merit according to hue values. Low hue amount in ear kernels in early period is an indication that yellow is more apparent. The fact that hue value is low shows that the colour of kernel is closer to yellow. Depending on the progress of periods hue values were found higher as a result of the increase of starch in outer shell colour. It has been found that hue value was higher compared to previous studies (Bozokalfa; Esiyok; Ugur, 2004; Esiyok; Bozokalfa; Ugur, 2004; Esiyok; Bozokalfa, 2005).

Table 2 - Husked ear weight values in sweet corn varieties (g).

\begin{tabular}{|c|c|c|c|c|}
\hline \multirow[b]{2}{*}{ Dates (A) } & \multicolumn{4}{|c|}{ Cultivation type } \\
\hline & Variety & Seed sowing & Seedling planting & Mean \\
\hline \multirow{6}{*}{5 May } & 2201 & 168.17 & 235.87 & 202.02 \\
\hline & Challenger & 217.93 & 244.10 & 231.02 \\
\hline & Merit & 205.13 & 231.83 & 218.48 \\
\hline & Sunshine & 208.13 & 215.20 & 211.67 \\
\hline & Yellow baby & 170.03 & 287.08 & 228.56 \\
\hline & Mean & 193.88 & 242.82 & 218.35 \\
\hline \multirow{6}{*}{15 May } & 2201 & 154.73 & 239.07 & 196.90 \\
\hline & Challenger & 141.53 & 140.82 & 141.18 \\
\hline & Merit & 221.63 & 256.73 & 239.18 \\
\hline & Sunshine & 169.35 & 234.50 & 201.93 \\
\hline & Yellow baby & 203.40 & 228.73 & 216.07 \\
\hline & Mean & 178.13 & 219.97 & 199.05 \\
\hline \multirow{6}{*}{25 May } & 2201 & 82.17 & 228.13 & 155.15 \\
\hline & Challenger & 76.10 & 213.40 & 144.75 \\
\hline & Merit & 157.60 & 271.73 & 214.67 \\
\hline & Sunshine & 141.53 & 202.00 & 171.77 \\
\hline & Yellow baby & 94.00 & 210.87 & 152.44 \\
\hline & Mean & 110.28 & 225.23 & 167.75 \\
\hline \multirow{5}{*}{ Variety (B) } & 2201 & 135.02 & 234.36 & 184.69 \\
\hline & Challenger & 145.19 & 199.44 & 172.31 \\
\hline & Merit & 194.79 & 253.43 & 224.11 \\
\hline & Sunshine & 173.00 & 217.23 & 195.12 \\
\hline & Yellow baby & 155.81 & 242.23 & 199.02 \\
\hline Cultivation type (C) & & 160.76 & 229.34 & \\
\hline \multicolumn{5}{|c|}{ 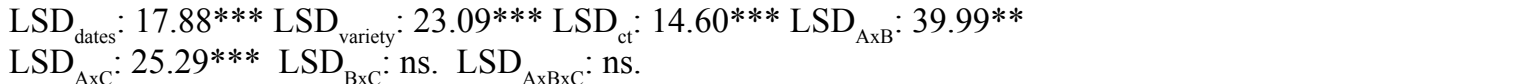 } \\
\hline
\end{tabular}


Table 3 - Total ear yield in sweet corn varieties $\left(\mathrm{kg} \mathrm{da}^{-1}\right)$.

\begin{tabular}{|c|c|c|c|c|}
\hline \multirow[b]{2}{*}{ Dates (A) } & \multicolumn{4}{|c|}{ Cultivation type } \\
\hline & Variety & Seed sowing & Seedling planting & Mean \\
\hline \multirow{6}{*}{5 May } & 2201 & 1010.33 & 2944.33 & 1977.33 \\
\hline & Challenger & 1590.67 & 2450.00 & 2020.34 \\
\hline & Merit & 2126.33 & 2796.67 & 2461.50 \\
\hline & Sunshine & 1943.67 & 2727.33 & 2335.50 \\
\hline & Yellow baby & 1462.67 & 1860.00 & 1661.34 \\
\hline & Mean & 1626.73 & 2555.67 & 2091.20 \\
\hline \multirow{6}{*}{15 May } & 2201 & 1233.67 & 3174.33 & 2204.00 \\
\hline & Challenger & 814.33 & 1023.33 & 918.83 \\
\hline & Merit & 1385.67 & 3594.33 & 2490.00 \\
\hline & Sunshine & 1033.67 & 3119.67 & 2076.67 \\
\hline & Yellow baby & 1558.67 & 2989.67 & 2274.17 \\
\hline & Mean & 1205.20 & 2780.27 & 1992.73 \\
\hline \multirow{6}{*}{25 May } & 2201 & 483.67 & 2237.67 & 1360.67 \\
\hline & Challenger & 188.67 & 2325.33 & 1257.00 \\
\hline & Merit & 1058.00 & 3133.00 & 2095.50 \\
\hline & Sunshine & 1291.00 & 2076.33 & 1683.67 \\
\hline & Yellow baby & 216.67 & 2169.33 & 1193.00 \\
\hline & Mean & 647.60 & 2388.33 & 1517.97 \\
\hline \multirow{5}{*}{ Variety (B) } & 2201 & 909.22 & 2785.44 & 1847.33 \\
\hline & Challenger & 864.56 & 1932.89 & 1398.72 \\
\hline & Merit & 1523.33 & 3174.67 & 2349.00 \\
\hline & Sunshine & 1422.78 & 2641.11 & 2031.95 \\
\hline & Yellow baby & 1079.34 & 2339.67 & 1709.50 \\
\hline Cultivation type (C) & & 1159.85 & 2574.75 & \\
\hline
\end{tabular}

ns: no significant; $p<0.05 * ; p<0.01 * * ; p<0.001$ ***.

Table 4 - TSS values in sweet corn varieties (\%).

\begin{tabular}{ccccc}
\hline \multicolumn{5}{c}{ Cultivation type } \\
\hline Dates (A) & Variety & Seed sowing & Seedling planting & Mean \\
\hline \multirow{3}{*}{ 5 May } & 2201 & 6.73 & 10.30 & 8.52 \\
& Challenger & 9.27 & 9.00 & 9.14 \\
& Merit & 16.17 & 15.27 & 15.72 \\
& Sunshine & 13.23 & 18.50 & 15.87 \\
& Yellow baby & 17.30 & 17.30 & 17.30 \\
& Mean & 12.54 & 14.07 & 13.31 \\
\hline & & & Continue...
\end{tabular}


Table 4 - Continue...

\begin{tabular}{|c|c|c|c|c|}
\hline \multirow[b]{2}{*}{ Dates (A) } & \multicolumn{4}{|c|}{ Cultivation type } \\
\hline & Variety & Seed sowing & Seedling planting & Mean \\
\hline \multirow{6}{*}{15 May } & 2201 & 11.33 & 13.63 & 12.48 \\
\hline & Challenger & 13.20 & 10.50 & 11.85 \\
\hline & Merit & 15.07 & 21.87 & 18.47 \\
\hline & Sunshine & 20.37 & 22.20 & 21.29 \\
\hline & Yellow baby & 20.73 & 24.70 & 22.72 \\
\hline & Mean & 16.14 & 18.58 & 17.36 \\
\hline \multirow{6}{*}{25 May } & 2201 & 15.40 & 11.20 & 13.30 \\
\hline & Challenger & 12.00 & 9.67 & 10.84 \\
\hline & Merit & 26.20 & 19.20 & 22.70 \\
\hline & Sunshine & 26.80 & 21.53 & 24.17 \\
\hline & Yellow baby & 23.00 & 20.83 & 21.92 \\
\hline & Mean & 20.68 & 16.49 & 18.58 \\
\hline \multirow{5}{*}{ Variety (B) } & 2201 & 11.15 & 11.71 & 11.43 \\
\hline & Challenger & 11.49 & 9.72 & 10.61 \\
\hline & Merit & 19.15 & 18.78 & 18.96 \\
\hline & Sunshine & 20.13 & 20.74 & 20.44 \\
\hline & Yellow baby & 20.34 & 20.94 & 20.64 \\
\hline Cultivation type (C) & & 16.45 & 16.38 & \\
\hline \multicolumn{5}{|c|}{$\begin{array}{l}\operatorname{LSD}_{\text {dates }}: 1.40^{* * *} \operatorname{LSD}_{\text {variety }}: 1.80^{* * *} \operatorname{LSD}_{\mathrm{ct}}: \text { ns. } \operatorname{LSD}_{\mathrm{AxB}}: \text { ns. } \operatorname{LSD}_{\mathrm{AxC}}: 1.98^{* * *} \\
\operatorname{LSD}_{\mathrm{BxC}}: \text { ns. LSD } \\
\text { AxBxC: }\end{array}$} \\
\hline
\end{tabular}

Table 5 - Kernel chroma values in sweet corn varieties.

\begin{tabular}{ccccc}
\hline & \multicolumn{3}{c}{ Cultivation type } \\
\hline Dates (A) & Variety & Seed sowing & Seedling planting & Mean \\
\hline \multirow{5}{*}{ 5 May } & 2201 & 72.62 & 74.14 & 73.38 \\
& Challenger & 74.71 & 73.74 & 74.23 \\
& Merit & 71.14 & 71.77 & 71.46 \\
& Sunshine & 71.08 & 71.05 & 71.07 \\
& Yellow baby & 71.01 & 72.39 & 71.70 \\
& Mean & 72.11 & 72.62 & 72.37 \\
\hline 15 May & 2201 & 71.87 & 72.37 & 72.12 \\
& Challenger & 74.18 & 72.40 & 73.29 \\
& Merit & 73.30 & 69.62 & 71.46 \\
& Sunshine & 70.98 & 70.46 & 70.72 \\
& Yellow baby & 71.46 & 70.33 & 70.90 \\
& Mean & 72.36 & 71.04 & 71.70 \\
\hline
\end{tabular}


Table 5 - Continue...

\begin{tabular}{|c|c|c|c|c|}
\hline \multirow[b]{2}{*}{ Dates (A) } & \multicolumn{4}{|c|}{ Cultivation type } \\
\hline & Variety & Seed sowing & Seedling planting & Mean \\
\hline \multirow{6}{*}{25 May } & 2201 & 65.75 & 71.98 & 68.87 \\
\hline & Challenger & 67.75 & 73.43 & 70.59 \\
\hline & Merit & 64.37 & 70.28 & 67.33 \\
\hline & Sunshine & 65.09 & 69.61 & 67.35 \\
\hline & Yellow baby & 66.28 & 71.46 & 68.87 \\
\hline & Mean & 65.85 & 71.35 & 68.60 \\
\hline \multirow{5}{*}{ Variety (B) } & 2201 & 70.08 & 72.83 & 71.46 \\
\hline & Challenger & 72.21 & 73.19 & 72.70 \\
\hline & Merit & 69.60 & 70.56 & 70.08 \\
\hline & Sunshine & 69.05 & 70.37 & 69.71 \\
\hline & Yellow baby & 69.58 & 71.39 & 70.49 \\
\hline Cultivation type (C) & & 70.11 & 71.67 & \\
\hline
\end{tabular}

$\mathrm{LSD}_{\text {dates }}: 0.74 * * * \operatorname{LSD}_{\text {variety }}: 0.96^{* * *} \operatorname{LSD}_{\mathrm{ct}}: 0.61^{* * *} \operatorname{LSD}_{\mathrm{AxB}}: \mathrm{ns} . \mathrm{LSD}_{\mathrm{AxC}}: 1.05^{* * *} \operatorname{LSD}_{\mathrm{BxC}}:$ ns. $\operatorname{LSD}_{\mathrm{AxBXC}}: \mathrm{ns}$. ns: no significant; $p<0.05 * ; p<0.01 * * ; p<0.001 * * *$

Table 6 - Kernel hue ${ }^{\mathrm{o}}$ values in sweet corn varieties (\%).

\begin{tabular}{ccccc}
\hline & \multicolumn{3}{c}{ Cultivation type } \\
\hline Dates (A) & Variety & Seed sowing & Seedling planting & Mean \\
\hline \multirow{5}{*}{ 5 May } & 2201 & 179.14 & 179.52 & 179.33 \\
& Challenger & 179.22 & 179.25 & 179.24 \\
& Merit & 178.75 & 178.49 & 178.62 \\
& Sunshine & 179.38 & 179.26 & 179.32 \\
& Yellow baby & 179.20 & 178.89 & 179.05 \\
& Mean & 179.14 & 179.08 & 179.11 \\
\hline \multirow{5}{*}{ 15 May } & 2201 & 179.60 & 179.79 & 179.70 \\
& Challenger & 179.32 & 179.67 & 179.50 \\
& Merit & 179.21 & 178.89 & 179.05 \\
& Sunshine & 179.76 & 180.37 & 180.07 \\
& Yellow baby & 180.03 & 180.22 & 180.13 \\
& Mean & 179.58 & 179.79 & 179.69 \\
\hline \multirow{2}{*}{ 25 May } & 2201 & 179.37 & 179.88 & 179.63 \\
& Challenger & 179.24 & 179.79 & 179.52 \\
& Merit & 179.28 & 179.29 & 179.29 \\
& Sunshine & 179.77 & 180.27 & 180.02 \\
& Yellow baby & 179.17 & 180.24 & 179.71 \\
& Mean & 179.37 & 179.89 & 179.63 \\
\hline
\end{tabular}

Continue... 
Table 6 - Continue...

\begin{tabular}{|c|c|c|c|c|}
\hline \multirow[b]{2}{*}{ Dates (A) } & \multicolumn{4}{|c|}{ Cultivation type } \\
\hline & Variety & Seed sowing & Seedling planting & Mean \\
\hline \multirow{5}{*}{ Variety (B) } & 2201 & 179.37 & 179.73 & 179.55 \\
\hline & Challenger & 179.26 & 179.57 & 179.42 \\
\hline & Merit & 179.08 & 178.89 & 178.99 \\
\hline & Sunshine & 179.64 & 179.97 & 179.80 \\
\hline & Yellow baby & 179.47 & 179.78 & 179.63 \\
\hline Cultivation type (C) & & 179.36 & 179.59 & \\
\hline $\mathrm{LSD}_{\text {dates }}: 0.16^{* * *} \mathrm{LSD}$ & $0.20 * * * \mathrm{LSD}_{\mathrm{ct}}$ & $\mathrm{LSD}_{\mathrm{AxB}}: 0.35^{*}$ & ${ }_{\mathrm{CC}}: 0.22^{* *} \mathrm{LSD}_{\mathrm{BxC}}:$ & $\mathrm{D}_{\mathrm{AxBxC}}: 0.49^{*}$ \\
\hline
\end{tabular}

\section{CONCLUSIONS}

In the study that was conducted by using five sweet corn varieties, seeds were sown and seedlings were planted on 5 May, 15 May and 25 May. According to the results, the varieties of Merit and Sunshine seem to be promising in terms of ear yield and plant specifications. It is necessary for earliness to be done with seedling planting. For putting the product on the market, farming with seeds may provide certain advantages in late season.

As a result of the rainy corn sowing period, some problems emerge in terms of seed germination and output and some decays occur in seeds. This challenge can be overcome with seedling planting in cultivation. Along with that, the power of seed to germinate can be enhanced through pre-germination applications towards seeds and seed output rates can be improved in cultivation with seed.

The fact that binary and triple interaction groups are generally important in the parameters analyzed in the study, cultivation period and way and the effects of the varieties on the features analyzed are depending on each other.

Almost one week earliness has been achieved in cultivation with seedling in the study. The highest yield and quality have been achieved in cultivation with seedling. Therefore it might be very important to carry out a production program in which cultivation with seedling and seed sowing in early period are handled together in terms of prolonging harvest period. In such kind of programming it is necessary to achieve output success in seed sowings. It might yield more fruitful results to conduct the study with mulching applications in terms of earliness.

\section{REFERENCES}

ANIL, H.; SEZER, I. A Study on the effects of different sowing time and transplanting on the yield, yield components and some quality characteristics in sweet corn at Carsamba Plain. OMU. Journal of Agricultural Faculty. 18(2):17-23, 2003.

BOYETTE, M.D.; WILSON, L.G.; ESTES, E.A. Postharvest cooling and handling of sweet corn in North Carolina, AG-413-4. N.C. Agricultural Extension Service. North Carolina, 1990. $\mathrm{p}$.

BOZOKALFA, M.K.; ESIYOK, D.; UGUR, A. Determination of yield quality and plant characteristic of some sweet corn (Zea mays L. var. saccharata) varieties as main and second crop in Aegean Region.

The Journal of Agricultural Faculty of Ege University. 41(1):11-19, 2004.

ESIYOK, D.; BOZOKALFA, M.K. The effects of sowing and planting dates on yield and some agronomic properties of sweet corn (Zea mays L. var. saccharata).

The Journal of Agricultural Faculty of Ege University. 42(1):35-46, 2005.

ESIYOK D.; BOZOKALFA M.K.; UGUR A. Determination of yield quality and some plant characteristic of some sweet corn (Zea mays L. var. saccharata) varieties in different location. The Journal of Agricultural Faculty of Ege University. 41(1):1-9, 2004.

IDIKUT, L.; CESUR, C.; TOSUN, S. Effect of planting dates and growing techniques on green yield and some characters of sweet corn. KSU Journal of Science and Engineering. 8(1):91-100, 2005. 
KACAR, B.; KATKAT, A.V. Plant Nutrition. Uludag University Broadcast. (127):1-595, 1998.

KWABIAH, A.B. Economic evaluation of production methods for sweet corn in a cool climate.

Journal of Vegetable Crop Production. 10(2):7387, 2004.

LUCHSINGER, L.A.; CAMILO, F.F. Sweet corn cultivars and their behavior with different sowing dates in the $6^{\text {th }}$ Region of Chile. IDESIA. 26(2):4552,2008 .

NAJEEB S. et al. Popularization of sweet corn (Zea mays L. saccharata) under temperate conditions to boost the socioeconomic conditions. Maize Genetics Cooperation Newsletter. 85:54$59,2011$.

OKTEM, A.; OKTEM, A.G.; COSKUN, Y.

Determination of sowing dates of sweet corn (Zea mays L. saccharata Sturt.) under Sanliurfa conditions.

Turkish Journal of Agriculture and Forestry. 28(2):83-91, 2004.

SARI, N.; ABAK, K. Effects of the low tunnel and sowing dates on the yield, plant growth and some agronomic characteristics of sweet corn (Zea mays L. var. saccharata). Turkish Journal of Agriculture and Forestry. 21(3):207-211, 1997.
TUNCAY, O.; BOZOKALFA, M.K.; ESIYOK, D. Determination of ear characteristic and technological properties of some sweet corn (Zea mays L. var. saccharata) varieties as main and second crop. The Journal of Agricultural Faculty of Ege University. 42(1):47-58, 2005.

TURGUT, I. Effects of plant populations and nitrogen doses on fresh ear yield and yield components of sweet corn (Zea mays saccharata Sturt.) grown under Bursa conditions. Turkish Journal of Agriculture and Forestry. 24(3):341-348, 2000.

TURGUT, I.; BALCI, A. Effect of different sowing dates on fresh ear yield and yield components of sweet corn (Zea mays saccharata Sturt.) cultivars under Bursa conditions. The Journal of Agricultural Faculty of Uludag University. 16(2):79-91, 2002.

WALKER, S. Home and market garden sweet corn production (Revised paper, Original author: George W. Dickerson, former Extension Horticulture Specialist). Cooperative Extension Service College of Agricultural, Consumer and Environmental Sciences, New Mexico State University. <http://aces.nmsu.edu/pubs/_h/h-223. pdf $>$. Access in: 15 dec., 2013.

WILLIAMS, M.M. Sweet corn growth and yield responses to planting dates of the North Central United States. Hortscience. 43(6):1775-1779, 2008. 